\title{
THE DECISION TO BUILD A FENCE: A REAL-OPTION PROBLEM
}

\author{
Garland Simmons \\ Stephen F. Austin State University • Nacogdoches, TX
}

\section{ABSTRACT}

Real-option methods of Net Present Value (NPV) analysis are applied to understand a capital budgeting decision concerning flexibility. The capital budgeting problem under study here is the decision of whether Spade Ranch (Spade) should build a fence. If this fence is built, then a hay-meadow could be converted into pasture land, which would in turn permit the herd-size of the Spade Ranch to increase. However, this fence building does not require the Spade to take the newly-fenced land out of hay production and put it into cattle production. Instead, once the fence is built, the Spade has the ability to switch land use from hay production to cattle production and vice versa. The decision of whether or not to create this flexibility by fence-building is the crux of this paper. What is the value of flexibility? If the fence costs less than the value of this flexibility then we build the fence, otherwise no.

For two different scenarios, a linear programming model is employed to define the relationship of Economic Value Added (EVA) to the question of whether or not one should produce hay or cattle given that the existence of a fence permits a decision maker to switch back and forth between hay and cattle production. These two scenarios, each of which work under different pricing assumptions, produce different EVA results and different production choices.

From this scenario work, the paper moves to the question of NPV. Is the decision to build a fence a positive NPV investment decision or not? An option pricing model is used to approach this question. Given a fence that provides for the ability to switch back and forth between cattle and hay production, what is the value of choosing additional cattle production by giving up the additional production of hay for sale? As it turns out, the question of NPV for an investment that provides a firm more flexibility by switching from the production of one product to another can be answered. But the answer depends on the volatility of possible rates of return on investment for both hay and cattle production, and their correlation with one another. 


\section{INTRODUCTION}

In this paper real-option methods of Net Present Value (NPV) analysis are applied to understand a capital budgeting decision concerning flexibility. The capital budgeting problem under study here is the decision of whether Spade Ranch (Spade) should build a fence. If this fence is built, then a hay-meadow could be converted into pasture land which would in turn permit the herd-size of the Spade Ranch to increase. However, this fence building does not require the Spade to take the newlyfenced land out of hay production and put it into cattle production. Instead, once the fence is built, the Spade has the ability to switch back and forth from hay production to cattle production and vice versa. The decision of whether or not to create this flexibility by fence-building is the crux of this paper.

The inspiration for this problem comes from conversations with Mr. John C. Mast, owner of the Spade Ranch and other ranches in Texas and New Mexico. The historic Spade located in East Texas raises and sells beef cattle. The Spade can sell all the cattle and the hay that they could produce, but they have no control over either cattle or hay prices. Prices for these products that are sold by the Spade fluctuate a great deal, and so too do prices for many of their inputs - water, farmland, fuel, hay, and fertilizer. Management has chosen to accept the large price fluctuations in cattle prices: they do not employ derivative contracts to hedge against commodity price movements; but they have chosen to protect themselves against large price swings in water, farmland, and hay. Instead of renting pasture land and attendant water access, Spade ranch land and associated water rights are owned fee simple. Moreover, under current operating policies, the Spade produces more than enough grass and hay to feed their own cattle, so fluctuating prices for these inputs is of no immediate concern. But if enough of the Hay production of the Spade is transformed into cattle production, the need to go into the open market to purchase hay will be realized. Should management acquire the ability to increase their herd size at the expense of hay production?

This problem in real-option valuation is informed by a related linear programming problem that works on two scenarios, each with a different price for yearling calves which is one of the major products of the Spade. To make this linear programming problem work, an objective function, the maximization of economic profits, is described using real-world parameter estimates (and some not so realworld assumptions where need be) of the prices and variable costs and capital costs associated with hay and cattle production. And the linear programming problem constraints are described by productivity data that relates how many yearling calves and how much hay can be produced per acre of farmland. 
From the linear programming problem the paper moves to the question of net present value (NPV). Is the decision to build a fence a positive NPV investment decision? An option pricing model is used to approach this question. Given a fence that provides for the ability to switch back and forth between cattle and hay production, what is the value of choosing additional cattle production by giving up the additional production of hay for sale? As it turns out, the question of NPV for an investment that provides a firm more flexibility by switching from the production of one product to another can be answered. But the answer depends on the volatility of possible rates of return on investment for both hay and cattle production, and their correlation with one another.

It is hoped that in this real-option problem undergraduate business students can see the connection of a simple investment decision of whether to build a fence, which adds flexibility to a Texas ranch's ability to produce larger and smaller quantities of two products, hay and cattle. And then perhaps they can go on from that point to understand how to estimate the Net Present Value (NPV) of this flexibility.

Some results in this problem are counterintuitive to many beginning students. Unexpectedly, they find that the more volatile hay and cattle prices are, the more valuable the fence that is built. They also find that the smaller the correlation of hay with cattle prices, the more valuable the fence, and vice versa.

\section{DATA SOURCES AND DATA ESTIMATES}

Data reported in this paper concerning cattle prices, the costs of growing hay, agricultural land prices, and the cost of building fence are factual. Information about the costs of growing hay is taken from Wilder Ferreira of Clemson Extension. The web: http://www.clemson.edu/extension/aes/budgets/files/bermudagrass.pdf. This report is current as of January 2014. Information about cattle prices and land prices for agricultural land was secured from Mr. John C. Mast of Nacogdoches, Texas. This information is current as of March 2014. Information about the cost of fence building is taken from Jeff Caldwell of Agriculture.com. The web: http:// www.agriculture.com/news/livestock/what-will-a-new-fence-cost-this-year_3ar22518. This information is current as of February 29, 2012. Information about the daily consumption of grass by cattle was obtained from Dr. Ronald Lott, DVM, of Nacogdoches, Texas. This information is current as of April 4, 2014. 
From these data sources it is estimated that a fence around the perimeter of a 640 acre, square tract of land can be built for $\$ 2$ per linear foot: total cost equals $\$ 42,240$. (No holding pens or cattle loading chutes will be required.) The market value of 640 acres of farmland is estimated at $\$ 5,000$ per acre. So, the market value of these 640 acres is estimated to equal $\$ 3,200,000$. If put into cattle production, a 640 acre pasture could either permit the herd size to increase by 116 animal units (A cow and calf comprises one animal unit.) or permit the production of 3,200 tons of hay. The contribution per ton of hay produced for sale is estimated to equal $\$ 30$ per ton. The contribution per yearling calf sold is estimated to equal $\$ 1,000$. Cows eat about two percent of their body weight per day in grass or hay, something more than that if their diet is not supplemented by feed. So a 1,000 pound animal will eat twenty pounds of grass or hay per day.

\section{DATA ASSUMPTIONS}

Five acres should produce 25 tons of grass per year. One animal unit, a mother cow and her calf, consumes about 6 or 7 tons of grass per year. So we can easily justify the assumption that five acres will support one animal unit. So, why five acres? The cost of growing five tons of grass per acre per for cows to eat is not the same as for growing five tons per acre for producing hay to be sold. But when feeding cows the rancher can choose to use more acres to make grass than she would for making hay for sale - five acres per animal unit in this case. So the fertilizer, labor, capital equipment cost necessary to growing grass for producing hay for sale is reduced from what would be required to grow grass so that hay could be produced and sold. It is assumed in this study that if five acres are allocated for each animal unit, no cash outlays will be required to grow grass for the cows to eat. By contrast, five acres of hay production for sale will cost $\$ 3,750$ in fertilizer, labor, and capital equipment cost. And these five acres will produce 25 tons of hay, far more than pastureland where only 6-7 tons of grass production is needed to support an animal unit.

Some other inputs are also assumed. The cost of capital for the Spade Ranch is assumed to be ten percent. The standard deviation of possible rates of return on investment in raising cattle is assumed to be sixteen percent, as is the standard deviation of possible rates of return on investment in growing hay for sale. The correlation of the possible rates of return on investment in raising cattle with the possible rates of return on investment in growing hay for sale is unknown. The size of the pasture to be fenced (or not) is assumed to be equal to 640 square acres. Economic depreciation per cow is assumed to equal $\$ 60$ per year. The marginal tax rate is assumed to equal zero. 
The mortality problem associated with raising yearling calves are ignored, and so too is the problem of fertilizing and otherwise maintaining pastureland used for grazing cows and calves. Some other details that may prove important for a later problem are also ignored here. Accounting depreciation for tax purposes could be estimated with straight-line depreciation methods for five years to a zero salvage value. There are some small anticipated maintenance costs associated with a fence. But this paper ignores these costs as well as the benefits of a depreciation tax shield.

\section{THE PROBLEM OF THIS PAPER}

A new fence will permit the use of 640 acres of pasture for either cattle raising operations or for hay production. Currently, these 640 acres, located across a farm to market road from Spade Ranch headquarters, planted in Bermuda grass, could be used as a hay meadow for the production of hay for sale. But if a fence is built this hay meadow could be used instead for cattle production. Should management acquire the ability to increase their herd size at the expense of hay production? In this regard the problem of this paper is to value the flexibility associated with the decision to build a new fence on one of the Spade Ranch pastures in Nacogdoches County, Texas. If the Net Present Value of the decision to build this fence is positive, then the value of the Spade with the fence is larger than the value of the Spade without the fence. So how does one go about estimating this Net Present Value?

\section{TWO BUSINESS MODELS FOR ONE ENTERPRISE}

A cattle ranch grows grass for their cows to eat and some cattle ranches also grow grass so that they can produce hay for sale. If a ranch grows more grass than their cows can eat then they either store it for later use or the sell it. An acre that is fertilized and maintained for hay production will produce about five tons of grass per year. If hay is to be produced for sale, then the cows must be kept out of the pasture where it grows. To keep cows out of a hay meadow requires a fence. The initial cost of the fence is projected to be $\$ 42,240$. Fences are durable, but every ten to twenty years fences should be replaced. If the hay produced is to be sold, the contribution to economic value added per acre of hay sold equals $\$ 150$. Given that each acre produces five tons of hay, that contribution to economic value added per ton of hay produced for sale equals $\$ 30$. 
The business of growing hay for sale is not the same as the business of raising yearling calves for sale. When growing grass for feeding mother cows and their calves the cost per acre and the quantity of grass produced per acre is less. To grow grass in order to produce hay for sale requires an annual investment of $\$ 750$ per acre in fertilizer, labor and capital. To grow grass to feed cows is another matter. If five acres are allocated for each animal unit (a mother cow and her calf), it is assumed in this study that no cash outlays will be required to grow grass for the cows to eat. In fact some costs would be incurred to lime and fertilize the pastureland where cows and calves graze, but these costs are ignored.

To raise yearling calves for sale, mother cows are bred every year and from this a calf is produced. At the end of the year, these yearling calves are sold and then the cycle starts over again. Currently a yearling calf will bring $\$ 1,200$ at market. Mother cows can often produce eight to ten calves, one each year. Every year some of the older, less-productive mother cows are sold, hence there is depreciation which is assumed to equal $\$ 60$ per calf per year. So that calf production can continue, each mother cow sold must be replaced with a cow carrying a calf. Current cost of purchasing a young, healthy cow that has been bred is equal to $\$ 2,500$. Given an assumed weighted cost of capital equal to ten percent, the annual dollar cost of capital of investing in one cow that has been bred is equal to $\$ 250$. Also, since each calf requires a mother cow, the ratio of mother cows to calves should be maintained at one-to-one. From 640 acres 116 yearling calves can be produced every year and 116 mother cows can be maintained.

\section{A LINEAR PROGRAMMING ANALYSIS}

In our linear programing problem there is one objective function and three constraints. The objective is to maximize annual economic value which is a function of the prices and costs associated with yearling calf production and hay production. The objective function is shown below:

$$
\begin{gathered}
\operatorname{Max} \text { EVA }=\left(\mathrm{C}_{\text {calf }}\right)(\Delta \text { Calves })+\left(\mathrm{C}_{\text {hay }}\right)(\Delta \text { Hay })- \\
(\Delta \text { Depreciation }+\Delta \text { Capital Cost })(\Delta \text { Cows })
\end{gathered}
$$

Where: EVA is economic value added for one year; $\mathrm{C}_{\text {calf }}$ is a parameter variable, the dollar contribution to EVA from selling one yearling calf; $\Delta$ Calves is a choice variable, the number of yearling calves raised for sale; $\Delta$ Hay is a choice variable, tons of hay; $\mathrm{C}_{\text {hay }}$ is a parameter value, the dollar contribution to EVA from 
selling one ton of hay; $\Delta$ Depreciation is a parameter variable, the dollar value of economic depreciation per year for one mother cow; $\Delta$ Capital Cost is a parameter value, the dollar value of capital cost per animal unit for one year; $\Delta$ Cows is a choice variable, the number of mother cows maintained. With regard to parameter values, for both scenarios below: $C_{\text {hay }}=\$ 30$ per ton of hay sold; $\Delta$ Depreciation $=\$ 60$ per mother cow; $\Delta$ Capital Cost $=\$ 250$ per number of mother cows; for one scenario below: $C_{\text {calf }}=\$ 1,200$ per yearling calf sold, and for the other scenario $C_{\text {calf }}=\$ 1,000$ per yearling calf sold.

There are three constraints. The first constraint defines a relationship between the number of yearling calves raised for sale every year and the number of mother cows:

$$
\Delta \text { Calves }-\Delta \text { Cows }=0
$$

In this paper, if the land to be fenced is to be used for cattle production, then the herd should increase: $\Delta$ Calves and $\Delta$ Cows both increase in a one-to-one relationship. If the land to be fenced is to be used for hay production, then the herd will not increase in size: $\Delta$ Calves and $\Delta$ Cows are both estimated to equal zero in this case. The second constraint defines how the 640 acres is divided between cow and calf production and hay production:

$$
\left(\mathrm{L}_{\text {calf }}\right)(\Delta \text { Calves })+\left(\mathrm{L}_{\text {cow }}\right)(\Delta \text { Cows })+\left(\mathrm{L}_{\text {hay }}\right)(\Delta \text { Hay }) \leq 640 \text { acres }
$$

Where: $L_{\text {calf }}$ is a parameter value, the number of acres of land required to raise one yearling calf - in both scenarios below $L_{\text {calf }}=2.5$ acres per yearling calf; $\mathrm{L}_{\text {hay }}$ is a parameter value, the number of acres required to raise one ton of hay for sale - in both scenarios below $\mathrm{L}_{\text {hay }}=0.20$ acres per ton of hay produced for sale; $\mathrm{L}_{\text {cow }}$ is a parameter value, the number of acres of land required to maintain one mother cow -- in both scenarios below $\mathrm{L}_{\text {cow }}=2.5$ acres per mother cow. The third constraint defines all choice variables, the number of yearling calves raised, the number of mother cows to be maintained, and the number of tons of hay produced for sale, $\Delta$ Calves, $\Delta$ Cows, and $\Delta$ Hay, to be positive quantities. 
Two scenarios, each with a different contribution for yearling calves produced and sold, are considered in the light of this linear programming model. In Table 1 below the contribution to EVA for each yearling calf produced and sold $\left(\mathrm{C}_{\text {calf }}\right)$ is permitted to equal $\$ 1,200$ and the contribution to EVA for each ton of hay produced for sale $\left(\mathrm{C}_{\text {hay }}\right)$ is permitted to equal $\$ 30$ per ton. In Table 2 below the contribution to EVA for each yearling calf produced and sold $\left(\mathrm{C}_{\text {calf }}\right)$ is permitted to equal $\$ 1,000$ which is less than that of the first scenario, and as before the contribution to EVA for each ton of hay produced for sale $\left(\mathrm{C}_{\text {hay }}\right)$ is permitted to equal $\$ 30$ per ton. In Table 1 one sees that the best choice when calves are priced at $\$ 1,200$ each is to produce 116 calves and 20 hay for sale. In Table 2 ones sees that the best choice when calves are priced at $\$ 1,000$ is to produces 3,200 tons of hay and no calves. In both scenarios, both tables, EVA is found to be positive.

\section{Table 1}

Higher Prices for Calves Make It Feasible To Curtail Hay Production In Favor of Increased Cattle Production

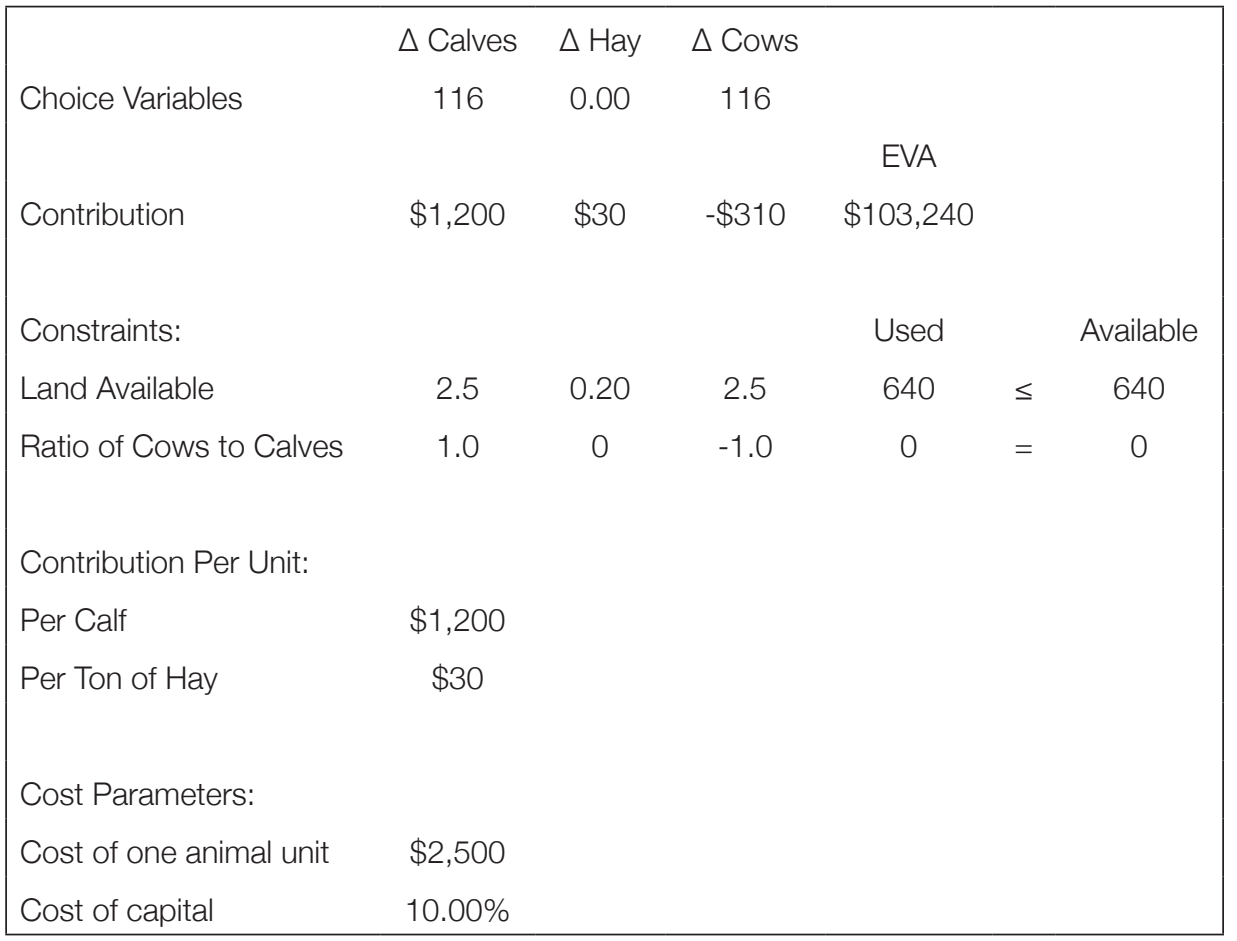


Table 2

Current Prices for Calves Make It Feasible To Increase Hay Production

\begin{tabular}{|c|c|c|c|c|c|c|}
\hline & $\Delta$ Calves & $\triangle$ Hay & $\triangle$ Cows & & & \\
\hline \multirow[t]{2}{*}{ Decision Variables } & 0 & 3,200 & 0 & & & \\
\hline & & & \multicolumn{4}{|c|}{ EVA } \\
\hline Contribution & $\$ 1,000$ & $\$ 30$ & $-\$ 310$ & \multicolumn{3}{|l|}{$\$ 96,000$} \\
\hline Constraints: & & & & Used & & Available \\
\hline Land Available & 2.5 & 0.20 & 2.5 & 640 & $\leq$ & 640 \\
\hline Ratio of Cows to Calves & 1.0 & 0 & -1.0 & 0 & $=$ & 0 \\
\hline \multicolumn{7}{|l|}{ Contribution Per Unit: } \\
\hline Per Calf & $\$ 1,000$ & & & & & \\
\hline Per Ton of Hay & $\$ 30$ & & & & & \\
\hline \multicolumn{7}{|l|}{ Cost Parameters: } \\
\hline Cost of one animal unit & $\$ 2,500$ & & & & & \\
\hline Cost of capital & $10.00 \%$ & & & & & \\
\hline
\end{tabular}

\section{AN OPTION PRICING MODEL ANALYSIS}

In these two scenarios above one finds the Spade generating positive EVA as they respond to changing prices (contribution per unit). The Spade is behaving in an optimal fashion in each of these scenarios. In one scenario as they optimize they choose to produce hay for sale and in the other as they optimize choose to produce yearling calves for sale. The existence of a fence provides for the flexibility to move from one optimum to another optimum. Without the fence the Spade cannot switch back and forth from hay production to cattle production. With the fence they can. Given that the Spade can create EVA in two ways, by in some circumstances selling hay and in other circumstances by selling cows, this flexibility to switch back and forth between these two products has itself economic value. The decision of whether or not to create this flexibility by fence-building is the crux of this paper. What is the value of flexibility? If the fence costs less than the value of this flexibility then we build the fence, otherwise no. To see this consider the future value of flexibility. 
$\mathrm{E}_{\mathrm{T}}$ is the uncertain future value at time period one of an option to increase the cattle herd size by an amount equal to $\Delta$ Calves $+\Delta$ Cows $=116$ animal units, by giving up a quantity of hay production equal to $\Delta$ (Hay) $=3,200$ tons. In this case equal to $\mathrm{E}_{\mathrm{T}}=\operatorname{MAX}[0, \mathrm{FV}(\Delta$ Calves $+\Delta$ Cows $)-\mathrm{FV}(\Delta$ Hay $)]$. This uncertain future value is the maximum of two future values, one associated with calf production and the other associated with hay production. In the circumstances when the choice to produce hay is optimum this future value is larger than the future value of the choice to produce calves, and vice versa. An option pricing model that estimates the present value of these possible future values is provided below. This model is a specialization of the work done by (Margrabe, 1978). The present value of the option to take cattle production in exchange for hay production is equal to the value of flexibility that comes from the decision to build a fence.

$$
E_{0}=\mathrm{PV}(\Delta \text { Cows }+\Delta \text { Calves }) \mathrm{N}\left(d_{1}\right)-\operatorname{PV}(\Delta \text { Hay }) N\left(d_{2}\right)
$$

$\mathrm{E}_{0}$ is the present value of an option to increase the cattle herd size by an amount equal to $\Delta$ (Cows) $=116$ animal units, by giving up a quantity of hay production equal to $\Delta$ (Hay) $=3,200$ tons.

$\mathrm{PV}(\Delta$ Calves $+\Delta$ Cows $)$ the present value of the Spade Ranch if cattle herd size increases by 116 animal units and if hay production does not increase, which is the result if the 640 acres to be fenced is devoted to cattle production instead of hay production. Given this choice $\mathrm{PV}(\Delta$ Calves $+\Delta$ Cows) is estimated to equal the value of the 640 acres to be fenced, $\$ 3,200,000$ plus the value of 116 animal units, $\$ 290,000$. This total equals $\$ 3,490,000$.

$\mathrm{PV}(\triangle$ Hay $)$ is the present value of the Spade Ranch if hay production for sale increases by 3,200 tons and if cattle production does not increase, which is the result if the 640 acres to be fenced is devoted to hay production instead of cattle production. Given this choice PV ( $\triangle$ Hay) is estimated to equal the value of the 640 acres of land to be fenced, $\$ 3,200,000$, plus the value of a 3,200 ton hay crop produced for sale from this 640 acres, which is equal to $\$ 576,000$. This total equals $\$ 3,776,000$.

$\sigma_{\Delta \mathrm{C}}^{2}$ the variance of possible (instantaneous) rates of return on the present value of the decision to change cattle herd size equal to $\Delta$ Calves $+\Delta$ Cows. In this paper $\sigma_{\Delta \mathrm{C}}^{2}$ is assumed to equal 16 percent squared.

$\sigma_{\Delta \mathrm{H}}^{2}$ the variance of possible (instantaneous) rates of return on the present value of the decision to change hay production equal to $\Delta$ Hay. In this paper $\sigma_{\Delta \mathrm{H}}^{2}$ is assumed to equal 16 percent squared. 
$\rho$ is the correlation coefficient measuring the possible (instantaneous) rates of return on the present values of the decisions to change both cattle and hay production. In this paper different values for this correlation coefficient are assumed in order to study the effect of changes in correlation on the option to increase cattle production by giving up an increase in hay production.

$$
\sigma^{2}=\sigma_{\Delta \mathrm{C}}^{2}+\sigma_{\Delta \mathrm{H}}^{2}-2 \rho_{\Delta \mathrm{C}, \Delta \mathrm{H}} \sigma_{\Delta \mathrm{C}} \sigma_{\Delta \mathrm{H}}
$$

And where $\sigma^{2}$ is the variance of each possible (instantaneous) difference between the state-contingent rate of return on investment in cattle production and in hay production:

$$
\sigma^{2}=\sigma_{\Delta \mathrm{C}}^{2}+\sigma_{\Delta \mathrm{H}}^{2}-2 \rho_{\Delta \mathrm{C}, \Delta \mathrm{H}} \sigma_{\Delta \mathrm{C}} \sigma_{\Delta \mathrm{H}}
$$

And where a $\mathrm{z}$ number equal to $\mathrm{d}_{1}$ under a standardized normal density

$$
d_{1}=\frac{\ln \left(\frac{P V(\Delta C)}{P V(\Delta H)}\right)+\frac{1}{2} \sigma^{2} T}{\left(\frac{\sigma}{\sqrt{T}}\right)}
$$

And where a $\mathrm{z}$ number equal to $\mathrm{d}_{2}$ under a standardized normal density

$$
d_{2}=d_{1}-\left(\frac{\sigma}{\sqrt{T}}\right)
$$


In Table 3 below a solution to the value of an option to exchange hay production for calf production is illustrated given certain parameter value assumption.

Table 3

Inputs and Solution: Valuing The Option to get Cattle Production by giving up Hay Production

\begin{tabular}{|c|c|c|}
\hline$P V(\triangle C)$ & $\$ 3,490,000$ & Present value of cow/ calf investment \\
\hline$P V(\Delta H)$ & $\$ 3,776,000$ & Present value of hay investment \\
\hline$T$ & 1 & One year \\
\hline$\sigma^{2}$ & 0.01024 & $\begin{array}{l}\text { Variance of difference of rates of return on hay and cattle } \\
\text { investments when correlation equals } 0.80 \text { and both } \sigma_{\Delta C} \\
\text { and } \sigma_{\Delta H} \text { equal } 16 \text { percent. }\end{array}$ \\
\hline$\sigma$ & 0.101193 & $\begin{array}{l}\text { Standard deviation of difference of rates of return on hay } \\
\text { and cattle investments when correlation equals } 0.80 \text { and } \\
\text { both } \sigma_{\Delta \mathrm{C}} \text { and } \sigma_{\Delta H} \text { equal } 16 \text { percent. }\end{array}$ \\
\hline$d_{1}$ & -0.72775 & $\begin{array}{l}\text { Assumes correlation of returns equal to } 0.80 \text { and both } \\
\sigma_{\Delta \mathrm{C}} \text { and } \sigma_{\Delta H} \text { equal } 16 \text { percent. }\end{array}$ \\
\hline$d_{2}$ & -0.82895 & $\begin{array}{l}\text { Assumes correlation of returns equal to } 0.80 \text { and both } \\
\sigma_{\Delta \mathrm{C}} \text { and } \sigma_{\Delta H} \text { equal } 16 \text { percent. }\end{array}$ \\
\hline$N\left(d_{1}\right)$ & 0.23338 & $\begin{array}{l}\text { Cumulative probability of a } z \text { number equal to } d_{1} \text { under a } \\
\text { standardized normal density }\end{array}$ \\
\hline$N\left(d_{2}\right)$ & 0.20357 & $\begin{array}{l}\text { Cumulative probability of a z number equal to } d_{2} \text { under a } \\
\text { standardized normal density }\end{array}$ \\
\hline$E_{0}$ & $\$ 45,834$ & $\begin{array}{l}\text { The value of an option to increase cattle production by } \\
\text { giving up an increase in hay production when correlation } \\
\text { equals } 0.80 \text { and both } \sigma_{\Delta C} \text { and } \sigma_{\Delta H} \text { equal } 16 \text { percent. }\end{array}$ \\
\hline
\end{tabular}


In Table 4 below students see that the correlation of possible rates of return on investment in hay production with those of investing in cattle production are decisive in determining the value of flexibility that is accorded by building a fence. Ceteris paribus, if correlation could be reduced then the value of flexibility is enhanced. Although not apparent from a reading of Table 4 below, it is the case that the larger the volatility of possible rates of return on investment in hay production and also the larger the volatility of possible rates of return on investment in cattle production, the larger the value of flexibility to switch back and forth between hay production and calf production.

Table 4

Correlation Affects the Value of the Option to Increase Cattle Production by Giving Up an Increase In Hay Production

\begin{tabular}{|ll|}
\hline Correlation of Returns & Option Value \\
0.80 & $\$ 45,834$ \\
0.40 & $\$ 135,820$ \\
0 & $\$ 203,786$ \\
-0.40 & $\$ 260,395$ \\
-0.80 & $\$ 209,859$ \\
\hline
\end{tabular}

Also important are the parameter estimates that one does not have to make in order to value an option to exchange one asset for another. Estimating expected rates of return on investment is not required when valuing flexibility. One does not have to estimate the expected return on investment in hay production, and one is not required to estimate the expected rate of return on investment in yearling calf production. Both of these parameter estimates are irrelevant to estimating the value of flexibility.

Now to the question of the Net Present Value (NPV) of flexibility. The NPV of the decision to build a fence that provides the flexibility of making optimal production choices in several different circumstances by switching back and forth between hay production and calf production as prices dictate, is equal to the option value less the cost of building the fence.

A fence that lasts many years has a larger NPV than a fence that costs the same amount of money but is not as durable. Why? For each year the fence last, there is another option that is provided. So in this case, if the fence were to last for twenty years, to calculate the NPV of building the fence, one would subtract the cost of building the fence from the values of twenty exchange options. 


\section{REFERENCES}

Arrow, Kenneth J. (1964). The Role of Securities in the Optimal Allocation of Risk Bearing. Review of Economic Studies 31(2), April 1964. pp. 91-96.

Black, Fisher, and Myron Scholes. (1973). The Pricing of Potions and Corporate Liabilities. Journal of Political Economy May-June 1973. 81(3), pp. 637-654.

Breeden, Douglas, and Robert Litzenberger. (1978). Prices of State-Contingent Claims Implicit in Option Prices. Journal of Business October 1978. 51(4), pp. 621-651.

Copeland, Tom, and Peter Tufano. (2004). A Real-World Way to Manage Real

Options. Harvard Business Review March 2004. 44(3), pp. 90-99.

Dantzig, George B. (1963). Linear Programming and Extensions. Princeton, New

Jersey: Princeton University Press.

Debreau, Gerald. (1959). The Theory of Value. New York: John Wiley \& Sons.

Fisher, Irving. (1930). The Theory of Interest. New York: The Macmillan Co.

Margrabe, William (1978). The Value of an Option to Exchange One Asset for Another. Journal of Finance March 1978. 33(1), pp. 177-186.

Merton, Robert C. (1973). The Theory of Rational Option Pricing. Bell Journal of Economics and Management Science Spring 1973. 4(1), pp.143-181.

Stern, Joel M. and John S. Shiely with Irwin Ross (2001). The EVA Challenge. New York: John Wiley \& Sons.

\section{BRIEF BIOGRAPHICAL SKETCH OF AUTHOR}

Garland (Mark) Simmons teaches business finance, financial statement analysis, and speculative markets to finance majors in the Rusche College of Business at Stephen F. Austin State University. His teaching and research are chiefly concerned with business decisions that can be approached with game-theory and linear programming or with pricing models that can be created and interrogated with logical methods of theorem and proof. His consulting work focuses on the construction and evaluation of equity and bond portfolios owned by foundations or trusts. 